\title{
Way of Banking Development Abroad: Branches or Subsidiaries
}

\author{
Eleftherios I. Thalassinos ${ }^{1}$, Bozhana Venediktova ${ }^{2}$, \\ Daniela Staneva-Petkova ${ }^{3}$, Vicky Zampeta ${ }^{4}$
}

\begin{abstract}
:
The purpose of the study is to show what kind of risks would have emerged for bank depositors if there are economical and political risks in a given country. For example, as is the case with the crisis in Greece, a threat or salvation for the banking organizational forms abroad exists regarding which type of bank development is more efficient, branches or subsidiaries. Respectively why do the big banks prefer to operate through branches and those which are focused on retail sales through subsidiaries? What impact could the political and economic risks have on the required reserves on the parent bank? Does the decision depend on the applied organizational form of the bank or on other reasons?
\end{abstract}

\section{Key Words:}

Foreign Banks, Organizational Form, Branches, Subsidiaries

JEL Classification F23, G21

\footnotetext{
${ }^{1}$ University of Piraeus, Greece, e-mail: thalassinos@ersj.eu

${ }^{2}$ University of National and World Economy, Department "Finance", e-mail:venediktovab@yahoo.com

${ }^{3}$ University of National and World Economy, Department "Management and Administration", e-mail: dcstaneva@gmail.com

${ }^{4}$ University of Piraeus, Greece, e-mail:Vicky.zampeta@gmail.com
} 


\section{Introduction}

During the crisis period Greek companies prefer to export their business into neighbouring countries such as Bulgaria and others (Thalassinos et al., 2010). It will be interesting to consider how this matter stands in the Greek banking industry as explained by Liapis et al. (2013) and if eventually they do it, what is the applied organizational form they have used. Is it through a branch or through a subsidiary? This is interesting to examine from the host country point of view. In our case we focus on Bulgaria to find out which banks are more resistant to crisis, those that carry out business through a branch or those that carry out business through subsidiaries.

As Emil Harsev, a Bulgarian economist, noted in his interview: "what for years has been expressed as the Bulgarian banking system highest priority, namely that it is dominated by large foreign banks, is now becoming its main defect" (Harsev, 2008). This is important to be taken into consideration, especially in a crisis period. Because if there are consequences for Bulgaria relating to banks' insolvency problems this insolvency is most possible to happen in the big foreign banks.

The present work has a good grasp of related studies. For example, there is a study about the operations of US 100 international top banks and their branches and subsidiaries in Eastern Europe and Latin America (Cerutti et al., 2007). During bankruptcy of an international bank of a country, there might be a possibility this bankruptcy to affect negatively the subsidiaries of this bank in another country. Nevertheless, the experience shows that this does not necessarily happen, when foreign international banks with, for example Bulgarian branches or daughter banks are bankrupted, even though this is not reflected in Bulgaria. A typical example is the Demir Bank's case as Harsev noted (2008).

\section{The Main Aim of the Paper}

The present study aims to put forward the investigation of the problem whether the organizational form influences the business outside of Greece regarding the Greek banking industry during the crisis. It hasn't been proved yet if it is more favourable to manage subsidiaries or branches? The study can be extended to the activities of the big banks in West Europe and their activities in East and South-East Europe, the countries that are not members of the Eurozone, where the foreign banks' activities are mostly distributed.

The organizational form is relevant to the operation of foreign banks because it can influence the structure of the local banking system, as well as it can endanger the profits and market share of the local banks, by influencing the price and the quality of banking services in the host country. 
While the subsidiaries are separate units and are not thus connected with the mother bank, the branches are more dependent and can accept direct help by the mother bank. This could have implications not only for the bank but also for the local regulators who care about the stability of the host country and for the local investors who care about the safety of their savings.

\section{Literature Review}

Recently the idea, that it is not necessary valid, the bank parent to assist a foreign branch is launched, if the bank is bankrupted due to extreme circumstances or as a result of certain actions by the Government of the host country. The reverse question will be interesting too. Are there circumstances where the international bank is not liquid enough to provide capital in its branches or subsidiaries? Is it necessary the subsidiary to suffer in the unaffected country? For example, Greece, Italy, and Spain have serious problems, as well as their banks (Thalassinos and Politis 2011). Is it necessary these problems to be transferred and to be "covered" by their branches and subsidiaries (Thalassinos and Kiriazidis 2003)?

Let's take for example Bulgaria as a country where the foreign banks prevail. (BNB, 2012). The supervisor must stop any attempt to export money from Bulgaria to a Western European State. Our surveillance system should not allow someone to artificially "pump" Bulgaria (Harsev, 2008). This is very true, when Western banks threaten that they will withdraw from the Balkans, simply because they will only harm.

The regulations in the country (Bulgaria) do not hamper the free funding of parent banks from local subsidiaries, provided that they are complied with the general rules set out in the relevant laws and regulations. This process occurs from 2009 onwards. Recent data on external debt show that from the beginning of 2011 there is a reduction of 486 million leva from the previous year. This is not scary because the subsidiary banks are affected because of the parent bank (Harsev, 2008). Of course there is a risk for the real deterioration in this case, given the fact that a considerable high proportion of the European ownership of financial institutions in Bulgaria belongs to the Greek banks, 24,4\% as pointed out by Sariiski, and Totev (2010).

While the subsidiaries are separate entities from parent banks, the branches are more dependent. Banks are directly responsible for their obligations. This may has implications not only for bank parent, but also for local regulators, which shall ensure the stability of the host country, and also for local depositors who take care of the safety of their savings (Cerutti et al., 2007). 


\section{The Empirical Evidence}

Table 1 presents the Greek banking industry in Bulgaria $^{2}$. The different organizational forms are associated with the degree of penetration in the host country. The branches are used more extensively when foreign operations are less in size, and are not oriented to retail sales. Greek banks hold about $28.7 \%$ of assets in the banking system and play the role of one of the main risks for liquidity in the banking system, which is assessed as "high" by external analysts (Sariiski and Totev, 2010). A foreign bank may specialize in a particular organizational form and according to regulations in its home country.

Table 1: Level of risk arising from the degree commitment to the economies of CEE from the Economy of Greece (Sariiski, 2011)

\begin{tabular}{|c|c|c|c|}
\hline & Banking sector & Real sector & Capital balance \\
\hline $\begin{array}{l}\text { High } \\
(15-25 \%)\end{array}$ & $\begin{array}{l}\text { Bulgaria, } \\
\text { Macedonia, Serbia }\end{array}$ & & Hungary \\
\hline $\begin{array}{l}\text { Middle } \\
(5 \%-15 \%)\end{array}$ & $\begin{array}{l}\text { Albania } \\
\text { Rumania }\end{array}$ & $\begin{array}{l}\text { Albania } \\
\text { Bulgaria } \\
\text { Macedonia }\end{array}$ & $\begin{array}{l}\text { Bulgaria, Croatia, } \\
\text { Litva, Poland, } \\
\text { Czech Republic, } \\
\text { Estonia, Slovakia }\end{array}$ \\
\hline $\begin{array}{l}\text { Low } \\
(5 \%)\end{array}$ & $\begin{array}{l}\text { Croatia } \\
\text { Czech Republic, } \\
\text { Estonia, Hungary, } \\
\text { Kazakhstan } \\
\text { Lithuania, Latvia, } \\
\text { Poland, Russia, } \\
\text { Slovakia, Ukraine }\end{array}$ & $\begin{array}{l}\text { Croatia } \\
\text { Czech Republic, } \\
\text { Estonia, Hungary, } \\
\text { Kazakhstan, } \\
\text { Lithuania, Latvia, } \\
\text { Poland, Romania } \\
\text { Russia, Serbia, } \\
\text { Slovakia,,Ukraine }\end{array}$ & $\begin{array}{l}\text { Albania, Kazakhstan } \\
\text { Latvia, Macedonia } \\
\text { Romania, Russia, } \\
\text { Serbia, Ukraine }\end{array}$ \\
\hline
\end{tabular}

Sources: Deutsche Bank Research. 2010, "Global Risk Analysis - A credit-less recovery", Credit Monitor - Eastern Europe May.2010. p.3.

Host country risks undeniably. In particular, the economic and political risks have opposite effect on banks' organizational form, which determines the differences in the response of the parent banks to their branches or subsidiaries, which on the other hand, determines the choice of the corresponding organizational form. There are 30 official licensed banks in Bulgaria, 7 of which are branches of foreign banks (BNB, 2012). In Bulgarian National bank's report we can trace the amount of their assets, number of employees, shareholders, i.e. the ownership etc. (BNB, 2012). The data show that subsidiaries prevail over foreign branches.

\footnotetext{
${ }^{2}$ Two of the biggest Bulgarian financial institutions, UBB and Post Bank, owned respectively of the Greek National Bank and Eurobank. Subsidiaries in Bulgarian have more "Emporiki" and "Pireos". Alpha Bank has registered the business in the Bulgarian as a branch (Sariiski, 2011).
} 
An appropriate methodology has been developed for researches in international banking that could be adjusted in respect of banks in Western Europe, which have branches in Eastern Europe. Thalassinos and Pociovalisteanu (2007) have examined the Romanian case with respect to stocks with important results concerning the effects of foreign financial entities in the country. The foreign banks that operate in Bulgaria are also a good example for this case (Cerutti, et al., 2007).

The main determinants for the organizational form of an international bank operating in Bulgaria are:

- the characteristics of the parent bank;

- the characteristics of the branch / subsidiary;

- the regulations in the country of origin;

- the regulations in the host country.

In the first determinant, the characteristics of the parent bank, the main issues taken into consideration are the size of the bank, its business orientation and its international activities (Cerutti, et al., 2007). When characterizing the bank branch the following elements are taken into account: The size of the branch in the host country as well as the number of employees in the host country.

In Bulgaria, for example, if there is bankruptcy of a foreign bank this will not affect the activity of the subsidiary in Bulgaria. As a rule Bulgarian subsidiaries of foreign banks rely on their headquarters abroad and while they rely on them, the problem is not serious. Calzolari and Loranth (2005) analyses the regulation of a multinational bank with a very simple and stylized model. However, his setting turns out to be versatile enough to deal with several important issues of multinational banks' (MNBs) regulation. They show that different organizational or representation forms generate very different regulatory responses for the same level of information.

Whether a foreign bank has to carry out on business through a branch or subsidiary abroad is determined by a number of factors such as the regulations in the country of the parent bank, the regulations and taxes in the host country, the desired degree of penetration in the host country, the type of operations the international bank carry out and the types of risks associated with the host country. This is the main concern of the consolidated banking supervision, how to present banks' business abroad either through a branch or through a subsidiary. In this regard the rapid expansion of the multinational banks (MNBs) is a source of new concerns for the regulators. MNBs can easily take advantage of poorly harmonized national supervision (Calzolari and Loranth, 2005; Thalassinos, 2007).

At the same time the regulation of a MNB in a given country can influence the behaviour of the bank and the regulators in the other country. Calzolari and Loranth 
(2005) has presented a simple framework examining the regulatory disciplinary actions that are performed by independent authorities in the case of MNBs.

The interference is an imperfect protection because regulators do not have all the information. A regulator that interferes in a bank might stop valuable investments, or alternatively might allow the continuation of bad projects (Calzolari, and Loranth, 2005). The shared responsibility between MNBs units provides higher incentives for regulatory intervention compared to the case when units are legally separated, since the regulator can reduce the costs of intervention in a given unit with assets from another. At the same time, however, the responsibility to insure depositors in both countries reduces the incentive to intervene in a given unit than when the regulator has to compensate the local depositors (Calzolari and Loranth, 2005). Some articles discuss what the location of the global financial integration and questions about the impact of the foreign ownership on the host economies is. Some see the multinational companies as agents of big capital and as financial stability means of the underdeveloped economies, while others emphasize the volatility created by the foreign investors (Carlin and Mayer, 2007). In the basis of these problems are the fundamental issues related with the investment behaviour of the connected companies in the multinational networks.

Internationalization is perhaps the main channel through which firms' growth materializes, even more so within a relatively large economy such as Italy. (De Bonis et al., 2008). The empirical findings of Bonis show that the length of such a relationship fosters both horizontal and vertical foreign direct investment (FDI) by firms as well as enterprises' choice to outsource production abroad (De Bonis et al., 2008). The rationale authors suggest for these findings hinges on the hypothesis that a longer relationship with the main bank helps secure external financing for these firms, which have become more opaque because of their internationalization (De Bonis et al., 2008). On the contrary, they detect no impact of the length of the relationship with the main bank on firms' propensity to export, suggesting that selling abroad alters enterprises' financial set up less than shifting production across the national borders (De Bonis et al., 2008). Their evidence suggests that preexisting strong bank-firm relationships support the internationalization of production by manufacturing firms (De Bonis et al., 2008). The European banking groups with foreign branches or subsidiaries, so-called "external Europeanization" represented in other EU countries, grow more rapidly especially for the Italian intermediaries than for the domestic assets flow. What is observed from the presentation of Italian banks abroad shows that bank branches and their representative offices progressively decreased over the years, while the subsidiaries are growing (Birindelli, 2010). This trend is valid for other banks as well, not just for Italians. The persistence in the banking behaviour in respect of the geographical distribution and organizational forms can be explained by past experience as well as with acquired "know-how". In particular, the author investigates the organizational and geographical choice that 
may be determined by the capabilities of the local market and by the complexity the clients followed in their trade and changing strategies (Birindelli, 2010). The author's analysis shows that the proximity to the customers positively influences the possibility banks to remain on the foreign markets, particularly when the banks operate abroad with branches or with representative offices.

Other studies with same determinants of the banking internationalization suggested the hypothesis "follow the customer", which leads to a positive and statistically significant relation between the banks and their international activities and the relocation of companies, which is measured by Foreign Direct Investments (FDI) and the foreign trade's flows. The trade flows and the bilateral FDI have also been taken as an indicator of the degree of integration between home and host country. The judicial and legal systems affect the international banking in several ways according to the different organizational forms of expansion while the presence of financial centres often attract foreign banks (Birindelli and Del-Prete, 2010). The barriers for the market entry reduce the possibilities for diversification of the portfolio risk-return. A similar effect comes from the restrictions of the outward FDI flows ${ }^{3}$.

With regard to the bilateral trade we have constructed an index of trade integration, which is measured by the ratio of exports and imports (from Italy to any other country) and the GDP. We also calculate the ratio between the FDI, divided by years, destination, and the GDP as well following Birindelli and Del-Prete (2010). This indicator shows how appropriate the relocation of local firms abroad is for production and for a bank in the process of internationalization (Birindelli and DelPrete, 2010; Thalassinos and Kiriazidis, 2003). The degree of openness of each country towards the foreign markets, which is represented by the trade flows and by FDI improves banking internationalization. It is important to note that banks with past experience in foreign markets are more likely to remain abroad than those without experience and "know-how". The costs for leaving these markets may reduce short-term correlation between bank internationalization and company relocation. The presence on the foreign markets is more likely for the larger and more profitable banks.

For the Italian banks the hypothesis "follow the customer" is an important factor that is supported by the positive impact of the FDI. The crisis changes the perceptions of the respondents for the country risk, exchange rate risks and reputation risks. The conclusion is that the effect from the crisis seems to have temporary character because banks do not seem to undertake change of their internationalization strategies due to the crisis; this is a conclusion in the European Structures, in September 2010 (Birindelli and Del-Prete, 2010). Therefore it is likely to increase

${ }^{3}$ Goldberg and Johnson, cit. in Birindelli, 2010 
the cross-border quickly when economic conditions improve, both within the EU and among the emerging markets in particular.

The competition in deposits is also high in some countries' economies such as Bulgaria, Hungary, Lithuania, Slovenia, partly due to the long process of catching up after the EU accession process and the related with it inconsistencies of the available domestic savings and investment opportunities in the country. Subsidiaries have increased their presence to $15 \%$ in 2009 as shown in Table 2.

Table 2 Representation, Supervision and Liability with Branch and Subsidiary MNBs

\begin{tabular}{|l|l|l|l|l|l|l|}
\cline { 2 - 7 } \multicolumn{1}{c|}{} & \multicolumn{3}{c|}{ Branch MNB } & \multicolumn{3}{c|}{ Subsidiary MNB } \\
\cline { 2 - 7 } & Regulation & $\begin{array}{l}\text { Deposit } \\
\text { insurance }\end{array}$ & $\begin{array}{l}\text { Cross- } \\
\text { liability }\end{array}$ & Regulation & $\begin{array}{l}\text { Deposit } \\
\text { insurance }\end{array}$ & $\begin{array}{l}\text { Cross- } \\
\text { liability }\end{array}$ \\
\hline $\begin{array}{l}\text { Home } \\
\text { unit }\end{array}$ & $\begin{array}{l}\text { Home } \\
\text { Regulator }\end{array}$ & $\begin{array}{l}\text { Home } \\
\text { Regulator }\end{array}$ & $\begin{array}{l}\text { Liable for } \\
\text { foreign } \\
\text { unit }\end{array}$ & $\begin{array}{l}\text { Home } \\
\text { Regulator }\end{array}$ & $\begin{array}{l}\text { Home } \\
\text { Regulator }\end{array}$ & $\begin{array}{l}\text { Not Liable } \\
\text { for foreign } \\
\text { unit }\end{array}$ \\
\hline $\begin{array}{l}\text { Foreign } \\
\text { unit }\end{array}$ & $\begin{array}{l}\text { Home } \\
\text { Regulator }\end{array}$ & $\begin{array}{l}\text { Home } \\
\text { Regulator }\end{array}$ & $\begin{array}{l}\text { Liable for } \\
\text { home unit }\end{array}$ & $\begin{array}{l}\text { Foreign } \\
\text { regulator }\end{array}$ & $\begin{array}{l}\text { Foreign } \\
\text { regulator }\end{array}$ & $\begin{array}{l}\text { Liable for } \\
\text { home unit }\end{array}$ \\
\hline
\end{tabular}

Source: Calzolari, 2005

\section{Cross-Border Intermediation}

According to ECB domestic credit institutions have increased their share in the EU banking sector in 2008, but their share has been decreased in 2009. By the end of 2009 almost $73 \%$ of total assets were own by domestic institutions, a figure that is marginally up compared to $71 \%$ in 2007 (ECB 2010).

The overall decline in the share of the foreign banks was almost entirely attributable to a decline in the share of branches from $15 \%$ to $12 \%$. Foreign subsidiaries increased their presence slightly in 2009 to $15 \%$. The decline in the market share of foreign branches was almost entirely attributable to institutions domiciled in the EU. In contrast, the United Kingdom and Belgium in particular substantially increased their foreign share in 2009, mainly because of the acquisitions by Santander and the acquisition of Fortis Bank by BNP Paribas.

Foreign banks continued to be more prevalent in the New Member States (NMS), although their aggregate share dropped from $72 \%$ to $69 \%$ in 2009 (ECB 2010). Unlike for the EU aggregate in which subsidiaries seemed to gain in importance, the decline was relatively low even across branches and subsidiaries in the NMS. 


\section{Conclusion}

The majority of the banking assets in the NMS were held by foreign subsidiaries (61\%) with those with an EU parent accounting for $57 \%$ of the market. By comparison, only $26 \%$ of the banking assets in the EU15 were held by foreign entities split fairly evenly between branches and subsidiaries. The market decrease in cross-border assets observed in wholesale and securities-related activities in 2008 levelled off during 2009. Integration in the retail banking segment, having generally lagged behind that in the other banking segments seems to have been affected by the financial crisis to a lesser extent. These developments have been also reflected in cross-border liabilities. In all, banks have clearly relied on their domestic counterparties rather than on their international peers during the financial crisis.

However, these developments are expected to be only temporary and the increasing trend of financial integration in the banking sector is expected to resume soon. Integration of the up to now fragmented retail markets is also expected to get new impetus from the advancing integration of the related market infrastructures and in particular from the wide-ranging application of the Single Euro Payments Area (SEPA) in the coming years.

\section{References}

BNB (2012), Banks in Bulgaria, October-December 2011.

BNB (2012), Bulgarian National Bank, [online], available at: www.bnb.bg BankSupervision/BSCreditInstitution/BSCIRegistrers/index.htm.

BNB, (2012), Bulgarian National Bank, [online], available at: www.bnb.bg/ BankSupervision/BSSupervisoryDisclosure/BSSDStatisticalData/index.htm?toLang=_B G [accessed 2012].

Birindelli,G. and Del-Prete, S. (2010), ’The Internacionalization of Italian banks:Direction and Organizational Reshaping", Journal of Money, Investment and Banking, Issue 18, pp. 105-125.

Calzolari, G. and Loranth G. (2005), "Regulation of Multinational Banks: A Theoretical Inquiry", Working Paper Series, ECB Research, No 431, pp. 1-41.

Carlin, W. and Mayer, C. (2008), Multinational Ownership and Subsidiary Investment, Oxford Financial Research Centre Economics Series Ref2008fe05.

Cerutti, E., Dell Ariccia, G. and Martinez-Peria, M.S. (2007), "How Banks Go Abroad: Branches or Subsidiaries?”, Journal of Banking \& Finance, Issue 31, pp. 1669-1692.

Calmes, C. and Theoret R. (2011), "Bank systematic risk and the business cycle: An empirical investigation using Canadian Data", Universite Du Quebec, Laboratory for Research in Statistics and Probability, ESG UOAM, Quebec, Canada.

De Bonis, R., Ferri, G. and Rotondi, Z. (2010), "Do bank-firm relationship influence firm internationalization?", MoFIP working paper No 37, pp. 1-25.

European Central Bank (2010), EU Banking Structures, Frankfurt am Main: s.n. 
Liapis, K., Rovolis, A., Galanos, C. and Thalassinos, I.E. (2013), "The Clusters of Economic Similarities between EU Countries: A View under Recent Financial and Debt Crisis", European Research Studies Journal, Vol. XVI, issue (1), pp. 41-66.

Sariiski, G. and Totev, S. (2010), "The Global Financial Crisis-Origin and Impact on the

Bulgarian Banking System", in Bartlett and Monastiriotis (eds), Facing the crisis bitter pills for the transforming Bulgarian Economy "South Eastern Europe after the Crisis: A New Dawn or Back to Business as Usual", London School of Economics, European Institute.

Thalassinos, I.E. and Politis, E.D. (2011), "International Stock Markets: A Co-integration Analysis", European Research Studies Journal, Vol. XIV (4), pp. 113-130.

Thalassinos, E. and Kiriazidis, Th. (2003), "Degrees of Integration in International Portfolio

Diversification: Effective Systemic Risk", European Research Studies Journal, Vol. VI(1-2), pp. 111-122.

Thalassinos, I.E. (2007), "Trade Regionalization, Exchange Rate Policies and EU-US Economic Cooperation", European Research Studies Journal, Vol. X(1-2), pp. 111-118.

Thalassinos, I.E., Deceanu, L., Pintea, M. and Zampeta, V. (2010), "New Dimensions of Country Risk in the Context of the Current Crisis: A Case Study for Romania and Greece”, European Research Studies Journal, Vol. XIII, (3), pp. 225-236.

Thalassinos, I.E. and Pociovalisteanu, D.M. (2007), "A Time Series Model for the Romanian Stock Market”, European Research Studies Journal, Vol. X(3-4), pp. 57-72. 